УДК 372.881 .161 .1

DOI: 10.23951/1609-624X-2020-1-61-69

\title{
ПРОФЕССИОНАЛЬНАЯ САМОРЕАЛИЗАЦИЯ В ПРЕДСТАВЛЕНИИ БУДУЩИХ УЧИТЕЛЕЙ РУССКОГО ЯЗЫКА
}

\section{Е. Н. Комарова}

\author{
Ивановский государственный университет, Иваново
}

\begin{abstract}
Введение. Важнейшей задачей современного образования является обеспечение возможностей для личностного и профессионального роста и для осуществления самореализации. Изложены основные подходы к изучению понятия «самореализация». Приводятся результаты анкетирования будущих учителей русского языка. Выявлены представления будущих учителей русского языка в отношении их профессиональной самореализации.

Материаль и методы. Исследование было проведено на основе анализа теоретических источников по проблеме самореализации и результатов анкетирования студентов филологического факультета. Авторская анкета состояла из трех вопросов открытого типа и четырех вопросов закрытого типа.

Результаты и обсуждение. Проанализированы различные подходы к пониманию названных понятий и обоснована собственная позиция по этому вопросу. По результатам анкетирования установлено, что 15 \% студентов третьего курса и 55 \% студентов четвертого курса уверены, что профессиональная самореализация подразумевает постоянное совершенствование в выбранной профессии и потребность в совершенствовании. Охарактеризованы потребности, возникающие у будущих учителей русского языка в ходе педагогической практики, которая является ключевым звеном между теоретическим обучением будущих учителей русского языка и их самостоятельной работой в образовательном учреждении.

Заключение. Самоактуализация понимается автором как тенденция к самореализации. А самореализация как процесс развития личности, предполагающий активную содеятельность с другими людьми, приложение собственных усилий. Выявлено, что критической точкой в становлении будущего учителя русского языка является педагогическая практика. До практики основными трудностями у студентов являются неуверенность в себе и нехватка знаний в области методических дисциплин. Это можно скорректировать опытом работы в качестве учителя. После педагогической практики основанными барьерами самореализации для студентов становятся отсутствие свободного времени у учителей русского языка и высокая интенсивность работы. Это заставляет будущих учителей русского языка сомневаться в правильности выбора сферы своей дальнейшей профессиональной деятельности. Поднимается вопрос о психолого-педагогическом сопровождении студентов во время практики.
\end{abstract}

Ключевые слова: самореализация, самоактуализация, профессиональная самореализация, будущие учителя русского языка, барьеры профессиональной самореализации.

\section{Введение}

Проблема самореализации является одной из центральных в психологии и рассматривается в других смежных дисциплинах: социологии, культурологии, педагогике. Самореализация как научная категория не получила однозначного теоретического определения. Существует множество точек зрения на данный феномен. Актуальность настоящего исследования определяется тем, что проблема профессиональной самореализации учителя русского языка не становилась предметом специального исследования.

\section{Результаты исследования}

В настоящее время нами проанализированы различные подходы к пониманию названных понятий и обоснована собственная позиция по этому вопросу. Приведены результаты анкетирования будущих учителей русского языка с целью выявить их представления в отношении их профессиональной самореализации. В опросе приняли участие 40 студентов-филологов (18 человек - студенты 3-го курса; 22 человека - студенты 4-го курса). По результатам анкетирования было установлено, что 44 \% студентов 3-го курса и $46 \%$ студентов 4-го курса осознают себя самореализующейся личностью.

А. Маслоу охарактеризовал самоактуализацию как желание человека достичь наивысшего уровня, добиться полного использования своих талантов, способностей и потенциала [1].

К. Роджерс убежден, что сущность природы человека ориентирована на движение вперед к определенным целям. С его точки зрения, главный мотив в жизни человека - это выявить свои лучшие качества, которые заложены от природы и максимально развить их [2].

Самоактуализация, по Гольдштейну, - основной мотив развития, это действия, направленные на восполнение или удовлетворение потребностей [3].

А. Адлер вводит понятие «стремление к превосходству», под которым понимает постоянное движение человека «к личностно значимым жизненным целям» [4]. 
Таким образом, в зарубежной психологии гуманистического направления самоактуализация рассматривается как мотивационная тенденция организма, как биологическое по своей природе явление, связанное с повышением напряжения биологической сущности человека.

В отечественной психологии самоактуализация осознается как центральное понятие современного гуманитарного знания и трактуется как явление социальное, как «непрерывный процесс, предполагающий осознание личностью перспективы собственного и общественного развития, умение видеть альтернативы, осознание ответственности за свой выбор, овладение индивидуальным стилем деятельности благодаря делу, которое человек делает своим» $[5$, с. 121$]$.

По мнению К. А. Абульхановой-Славской, понятие самоактуализации, без использования термина, осмысливалось С. Л. Рубинштейном как «направленность, активность личности, осуществляющей в конечном итоге опредмечивание, объективацию не только отдельных мотивов, устремлений, но и самой личности» $[6$, с. 68]. Рубинштейн рассматривает данный феномен как «интегральную характеристику личности, в которой соединены и динамическое, и содержательное, и отражательный (содержательный, предметный) аспект, и отношенческий (эмоциональный)» [там же].

В. И. Слободчиков и Е. И. Исаев понимают под самоактуализацией «процесс становления человека как субъекта собственной жизнедеятельности», который «требует освоения им норм и способов человеческой деятельности, основных смыслов и ценностей, регулирующих совместную жизнь людей в обществе» $[7$, с. 48].

А. Г. Асмолов определяет самоактуализацию как «самоосуществление «иных культур», имеющее своим источником преобразование норм данной культуры и творение в ходе контакта с миром новых норм, т. е. нормотворчество. В процессе самоактуализации рождаются интерсубъективные социальные миры» [8, с. 402]. Автор акцентирует внимание на том, что «поведение человека может быть понято только как история поведения, а психология личности - только как история развития изменяющейся личности в изменяющемся мире» [там же, с. 131].

Как видим, И. А. Витин, В. И. Слободчиков, Е. И. Исаев, С. Л. Рубинштейн, А. Г. Асмолов приписывают самоактуализации социальное начало. Они подчеркивают тенденцию к самоактуализации с учетом специфики конкретной деятельности и условий, в которых развивается личность.

Раскроем соотношение понятий «самореализация» и «самоактуализация». В своих публикациях мы уже обращались к проблеме самореализации человека [10], основываясь на работах Н. Е. Харламенковой и Р. 3. Сабанчиевой.

По мнению Н. Е. Харламенковой, самореализация проявляется как «стремление актуализировать, сохранять и расширять самого себя» $[11$, с. 56,59$]$ и представляет собой «механизм развития личности» [там же, с. 24]. Показателем самореализованности человека является испытываемое им ощущение личностной состоятельности применительно к возрасту: реализованность его дарований, способностей и талантов.

Р. 3. Сабанчиева рассматривает самоактуализацию как необходимую предпосылку, условие самореализации. По мнению автора, «самореализация достигается только тогда, когда у человека имеется сильный побудительный мотив» для личностного роста [12, с. 383].

Таким образом, понятия «самоактуализация» и «самореализация» являются близкими, но не тождественными. Под самоактуализаиией мы будем понимать тенденцию к самореализации, стремление реализовать свой потенциал, желание человека стать тем, кем он хочет, которое мобилизует внутреннюю силу личности. Самореализация - процесс развития личности, осуществление своих возможностей, предполагающее активную содеятельность с другими людьми, сотворчество, приложение собственных усилий. Самоактуализация существует во внутреннем плане личности (субъективный), а самореализация - во внешнем (объективный). Однако отметим, что в научных публикациях эти термины часто используются как синонимичные.

Процесс самореализации правомерно рассматривать в контексте различных отношений личности, в том числе отношения личности к деятельности.

По А. К. Марковой, «максимальная самореализация своих внутренних сил в профессиональной деятельности» [13, с. 112] осуществляется путем саморазвития средствами профессии, через осознание своих способностей и возможностей, своего личностного соответствия выполняемой деятельности, путем формирования и укрепления индивидуального стиля профессиональной деятельности.

Исключительно актуальной представляется готовность и способность личности к самореализации в педагогической деятельности, когда самореализация становится одним из важнейших факторов достижения профессионального успеха.

В. А. Сластенин рассматривает самоактуализацию личности будущего учителя как одну из важнейших задач высшей педагогической школы. По его мнению, в основу личностно ориентированных технологий должен быть положен диалогический подход, определяющий «...самоактуализацию и самопрезентацию личности учителя» [14, с. 355]. С точки зрения В. А. Сластенина, современная 
Комарова Е. Н. Профессиональная самореализащия в представлении будущих учителей...

\section{Таблица 1}

Основные представления ученых о самореализации в педагогике и психологии

\begin{tabular}{|c|c|c|}
\hline Автор & Определение самореализации & Признаки самореализующейся личности \\
\hline А. Маслоу & $\begin{array}{l}\text { «Желание человека стать тем, кем он } \\
\text { может стать по своей природе» }[1, \text { с. } 58]\end{array}$ & $\begin{array}{l}\text { «Принятие себя, других и природы; независимость; } \\
\text { более эффективное восприятие реальности; } \\
\text { непосредственность, простота и естественность; } \\
\text { автономность от мнения окружающих; глубокие } \\
\text { межличностные отношения; пиковые переживания; } \\
\text { креативность; философское чувство юмора» [1, с. 78] }\end{array}$ \\
\hline К. Роджерс & \begin{tabular}{|l|} 
«роцесс сохранения и развития себя, \\
максимального выявления лучших качеств \\
своей личности, заложенных в ней от \\
природы» [2, с. 196]
\end{tabular} & $\begin{array}{l}\text { «Открытость опыту; подвижность, адаптивность и } \\
\text { спонтанность; свобода в жизни; творчество» } \\
{[2, \text { с. } 210]}\end{array}$ \\
\hline К. Гольдштейн & $\begin{array}{l}\text { «Тенденция актуализировать свои } \\
\text { индивидуальные способности» [3, с. 117] }\end{array}$ & $\begin{array}{l}\text { «Формирование определенного уровня напряжения, } \\
\text { которое сделает возможной дальнейшую } \\
\text { упорядоченную деятельность» }[3, \text { c. } 117]\end{array}$ \\
\hline А. Адлер & «Стремление к превосходству» [4, с. 2] & $\begin{array}{l}\text { «Стремление реализовывать индивидуальные цели» } \\
{[4, \text { с. } 2]}\end{array}$ \\
\hline И. А. Витин & $\begin{array}{l}\text { «Процесс непрерывный, предполагающий } \\
\text { осознание личностью перспективы } \\
\text { собственного и общественного развития, } \\
\text { умение видеть альтернативы, осознание } \\
\text { ответственности за свой выбор, овладение } \\
\text { индивидуальным стилем деятельности } \\
\text { благодаря делу, которое человек делает } \\
\text { своим» } 9, \text { с. } 121] \\
\end{array}$ & $\begin{array}{l}\text { «Открытость; отношение к другим людям как } \\
\text { ценности (а не цели); способность к диалогическому и } \\
\text { полилогическому общению; способность } \\
\text { самостоятельно ставить цели и достигать их» [9, с. 121] }\end{array}$ \\
\hline С. Л. Рубинштейн & $\begin{array}{l}\text { «Интегральная характеристика личности, } \\
\text { в которой соединены и динамическое, и } \\
\text { содержательное, и отражательный } \\
\text { (содержательный, предметный) аспект, и } \\
\text { отношенческий (эмоциональный)» [6] }\end{array}$ & $\begin{array}{l}\text { «Переживание как источник человеческого познания } \\
\text { и изменения личности» [6] }\end{array}$ \\
\hline $\begin{array}{l}\text { В. И. Слободчиков, } \\
\text { Е. И. Исаев }\end{array}$ & $\begin{array}{l}\text { «Процесс становления человека субъектом } \\
\text { собственной жизнедеятельности, который } \\
\text { требует освоения им норм и способов } \\
\text { человеческой деятельности, основных } \\
\text { смыслов и ценностей, регулирующих } \\
\text { совместную жизнь людей в обществе» } \\
\text { [7, с. } 301]\end{array}$ & «Ответственность и самостоятельность» [7, с. 350] \\
\hline А. Г. Асмолов & \begin{tabular}{|l|} 
«Переход от формально-ролевого типа \\
взаимоотношений с окружающими к \\
личностно-смысловому типу \\
взаимоотношений в контексте социально- \\
исторического образа жизни» $[8$, с. 25$]$ \\
\end{tabular} & $\begin{array}{l}\text { «Умение осуществлять выбор, оценить последствия } \\
\text { принятого решения и держать за них ответ перед } \\
\text { собой и миром» }[8, \text { с. } 410]\end{array}$ \\
\hline
\end{tabular}

образовательная ситуация объективно требует становления учителя субъектом собственного профессионального развития [15].

С точки зрения А. В. Шинкоренко, профессиональная самореализация - это стремление педагогов и студентов - будущих педагогов к активному и творческому взаимодействию с окружающим миром [16].

Е. В. Андриенко, рассматривает самореализацию личности учителя в педагогическом процессе как спонтанный процесс. Но этот процесс должен быть целенаправленным и управляемым [17, с. 70].

М. Г. Сергеева, М. В. Донская и др. понимают под профессиональной самореализацией будущего специалиста процесс постоянной внутренней борьбы за совершенствование и реализацию творческого потенциала личности, достижение це- лостности и стремление к «самосовершенствованию» [18].

А. М. Гридчин, Е. Н. Шутенко и др. обосновывают внедрение современных информационных технологий в образовательный процесс вуза как стимуляторов процесса самореализации студентов [19]. Основными детерминантами самореализации в новом информационном пространстве выступают ориентация и навигация, эвристический поиск, создание коммуникативной и интерактивной среды [20].

Несмотря на значительное число публикаций в данной области, проблема профессиональной самореализации учителя русского языка не становилась предметом специального исследования.

Для того чтобы выявить представления об особенностях профессиональной самореализации будущих учителей русского языка, была составлена 
авторская анкета, состоящая из трех вопросов открытого типа и четырех вопросов закрытого типа. Вопросы были следующего содержания: какую личность Вы можете назвать самореализующейся? (вопрос открытого типа); считаете ли Вы себя самореализующейся личностью? (варианты ответа: однозначно да; да; скорее да; затрудняюсь ответить; скорее нет; нет; однозначно нет); насколько Вы испытываете потребность в самореализации в целом? (ответ оценивался по 10-балльной шкале, где 10 соответствует максимальной оценке, а 1 - минимальной); что Вы вкладываете в понятие «профессиональная самореализация»? (открытый вопрос); насколько Вы испытываете потребность в профессиональной самореализации? (ответ оценивался по 10-балльной шкале, где 10 соответствует максимальной оценке, а 1 - минимальной); считаете ли Вы, что владеете всем необходимым для осуществления профессиональной самореализации? (варианты ответа: однозначно да; да; скорее да; затрудняюсь ответить; скорее нет; нет; однозначно нет); что мешает Вам профессионально самореализовываться? (вопрос открытого типа).
Обработка данных осуществлялась путем подсчета среднего балла в ответе на закрытый вопрос и контент-анализа открытых вопросов.

Перейдем к результатам исследования.

Первый вопрос был направлен на то, чтобы узнать, какую личность будущие учителя русского языка считают самореализующейся.

Итак, будущие учителя русского языка отмечают следующие характеристики самореализующейся личности: успешность в каком-либо деле (данный показатель выделили 42 \% студентов 3-го курса и $33 \%$ студентов 4-го курса); постоянное развитие (данный показатель выделили $44 \%$ студентов 3-го курса и 33 \% студентов 4-го курса). Также респонденты 1-й группы отметили в качестве критерия самореализующейся личности независимость, а респонденты 2-й группы - разносторонность и открытость новому опыту.

Остановимся на субъективных представлениях будущих учителей русского языка о том, являются ли они сами самореализующейся личностью.

Осознают себя самореализующейся личностью 44 \% студентов 3-го курса и 46 \% студентов 4-го

Таблица 2

Представления будущих учителей русского языка о самореализующейся личности

\begin{tabular}{|l|c|c|}
\hline \multicolumn{1}{|c|}{$\begin{array}{c}\text { Характеристики самореализующейся } \\
\text { личности }\end{array}$} & Студенты 3-го курса, \% & Студенты 4-го курса, \% \\
\hline Успешна в каком-либо деле & 42,0 & 33,0 \\
\hline Независимая личность & 14,0 & 0,0 \\
\hline Постоянно развивающаяся личность & 44,0 & 33,0 \\
\hline Разносторонняя личность & 0,0 & 16,0 \\
\hline Открытая новому опыту & 0,0 & 18,0 \\
\hline Итого & 100,0 & 100,0 \\
\hline
\end{tabular}

Таблица 3

Субъективные представления будущухх учителей русского языка о том, являются ли они самореализуюшейся личностью

\begin{tabular}{|l|c|c|}
\hline \multicolumn{1}{|c|}{ Варианты ответа } & Студенты 3-го курса, \% & Студенты 4-го курса, \% \\
\hline Да & 14,0 & 36,0 \\
\hline Скорее да & 44,0 & 46,0 \\
\hline Затрудняюсь ответить & 28,0 & 18,0 \\
\hline Скорее нет & 14,0 & 0,0 \\
\hline Нет & 0,0 & 0,0 \\
\hline Итого & 100,0 & 100,0 \\
\hline
\end{tabular}

Таблица 4

Потребность в самореализацчии у будущчих учителей русского языка (по данным самооцуенки)

\begin{tabular}{|c|c|c|}
\hline Оценки & Студенты 3-го курса, \% & Студенты 4-го курса, \% \\
\hline 1 & 0,0 & 0,0 \\
\hline 2 & 0,0 & 0,0 \\
\hline 3 & 0,0 & 0,0 \\
\hline 4 & 0,0 & 0,0 \\
\hline 5 & 0,0 & 0,0 \\
\hline 6 & 28,0 & 9,0 \\
\hline 7 & 14,0 & 9,0 \\
\hline 8 & 14,0 & 27,0 \\
\hline 9 & 16,0 & 18,0 \\
\hline 10 & 28,0 & 37,0 \\
\hline Итого & $\mathbf{1 0 0 , 0}$ & $\mathbf{1 0 0 , 0}$ \\
\hline
\end{tabular}


Комарова Е. Н. Профессиональная самореализащия в представлении будущих учителей...

Потребность в самореализации у будущих учителей русского языка (по данным самооченки, средний балл)

\begin{tabular}{|c|c|c|}
\hline \multirow{2}{*}{ Средний балл } & Студенты 3-го курса, \% & Студенты 4-го курса, \% \\
\cline { 2 - 3 } & 8,0 & 8,7 \\
\hline
\end{tabular}

Таблица 6

Представления будущчих учителей русского языка о понятии «профессиональная самореализация»

\begin{tabular}{|l|c|c|}
\hline \multicolumn{1}{|c|}{ Представления } & Студенты 3-го курса, \% & Студенты 4-го курса, \% \\
\hline Успешность в выбранной профессии & 71,0 & 27,0 \\
\hline $\begin{array}{l}\text { Обладание 3УН и опытом в выбранной } \\
\text { профессии }\end{array}$ & 14,0 & 0,0 \\
\hline $\begin{array}{l}\text { Постоянное совершенствование в } \\
\text { выбранной профессии и потребность в } \\
\text { совершенствовании }\end{array}$ & 15,0 & 55,0 \\
\hline Передача ЗУН ученикам & 0,0 & 18,0 \\
\hline Итого & $\mathbf{1 0 0 , 0}$ & $\mathbf{1 0 0 , 0}$ \\
\hline
\end{tabular}

Таблица 7

Потребность в профессиональной самореализащии у будущих учителей русского языка

\begin{tabular}{|c|c|c|}
\hline Оценки & Студенты 3-го курса, \% & Студенты 4-го курса, \% \\
\hline 1 & 0,0 & 0,0 \\
\hline 2 & 0,0 & 0,0 \\
\hline 3 & 0,0 & 0,0 \\
\hline 4 & 0,0 & 0,0 \\
\hline 5 & 14,0 & 9,0 \\
\hline 6 & 0,0 & 18,0 \\
\hline 7 & 28,0 & 18,0 \\
\hline 8 & 14,0 & 28,0 \\
\hline 9 & 30,0 & 18,0 \\
\hline 10 & 14,0 & 9,0 \\
\hline Итого & $\mathbf{1 0 0 , 0}$ & $\mathbf{1 0 0 , 0}$ \\
\hline
\end{tabular}

Таблица 8 Потребность в профессиональной самореализации у будущих учителей русского языка (средний балл)

\begin{tabular}{|c|c|c|}
\hline \multirow{2}{*}{ Средний балл } & Студенты 3-го курса, \% & Студенты 4-го курса, \% \\
\cline { 2 - 3 } & 8,0 & 7,5 \\
\hline
\end{tabular}

Таблица 9

Представления будущих учителей русского языка о том, владеют ли они всем необходимым для профессиональной самореализации

\begin{tabular}{|l|c|c|}
\hline \multicolumn{1}{|c|}{ Варианты ответа } & Студенты 3-го курса, \% & Студенты 4-го курса, \% \\
\hline Да & 0,0 & 36,0 \\
\hline Скорее да & 0,0 & 27,0 \\
\hline Затрудняюсь ответить & 57,0 & 19,0 \\
\hline Скорее нет & 43,0 & 18,0 \\
\hline Нет & 0,0 & 0,0 \\
\hline Итого & $\mathbf{1 0 0 , 0}$ & $\mathbf{1 0 0 , 0}$ \\
\hline
\end{tabular}

курса. А 14 \% студентов 3-го курса и 36 \% студентов 4-го курса уверены, что они являются самореализующимися личностями.

Из табл. 3 мы видим, что у обеих групп выборки потребность в самореализации выше среднего (оценки по 10-балльной шкале от 6 и выше).

Далее остановимся на представлениях будущих учителей русского языка относительно понятия «профессиональная самореализация».

Трактуют понятие «профессиональная самореализация» как успешность в выбранной профессии 71 \% студентов 3-го курса и 27 \% студентов 4-го курса. Представляют профессиональную самореализацию как обладание знаниями, умениями и навыками в выбранной ими профессии 14 \% студентов 3-го курса. А 15 \% студентов 3-го курса и 55 \% студентов 4-го курса уверены, что профессиональная самореализация подразумевает постоянное совершенствование в выбранной профессии и потребность в совершенствовании. Но $18 \%$ студентов 4-го курса считают, что профессиональная самореализация учителя подразумевает передачу знаний, умений и навыков своим ученикам. Из табл. 5 видно, что у студентов 3-го курса преобла- 


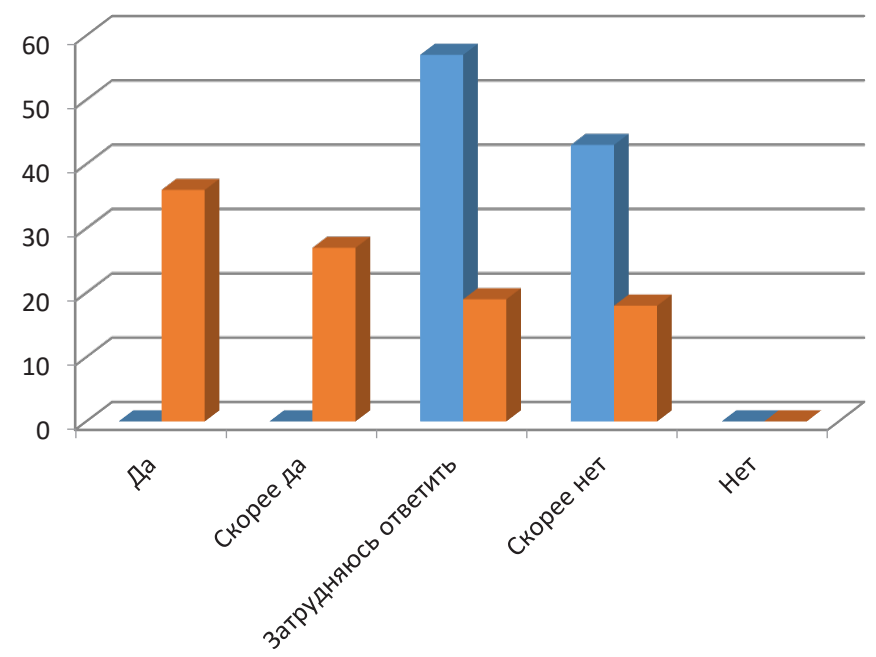

- Студенты 3-го курса

- Студенты 4-го курса

Рис. 1. Представления будущих учителей русского языка о том, владеют ли они всем необходимым для профессиональной самореализации

Таблица 10

Наличие барьеров у будущих учителей русского языка в их профессиональной самореализащии

\begin{tabular}{|l|c|c|}
\hline \multicolumn{1}{|c|}{ Трудности } & Студенты 3-го курса, \% & Студенты 4-го курса, \% \\
\hline Отсутствие практики & 28,0 & 0,0 \\
\hline $\begin{array}{l}\text { Отсутствие знаний по методическим } \\
\text { дисциплинам }\end{array}$ & 28,0 & 17,0 \\
\hline Неуверенность в себе & 16,0 & 0,0 \\
\hline Отсутствие мотивации & 28,0 & 33,0 \\
\hline $\begin{array}{l}\text { Сомнения относительно выбранной } \\
\text { профессии }\end{array}$ & 0,0 & 17,0 \\
\hline Отсутствие свободного времени & 0,0 & 33,0 \\
\hline Итого & $\mathbf{1 0 0 , 0}$ & $\mathbf{1 0 0 , 0}$ \\
\hline
\end{tabular}

дает абстрактное представление о профессиональной самореализации. У студентов 4-го курса после прохождения педагогической практики наблюдается тенденция более четкого представления этого понятия.

Результаты анкетирования показывают, что будущие учителя русского языка испытывают потребность в своей профессиональной самореализации (оценки по 10-балльной шкале от 5 и выше).

Средние баллы по двум группам выборки представлены в табл. 7.

Следующий вопрос был направлен на то, чтобы узнать мнение будущих учителей русского языка о том, есть ли у них все необходимое для того, чтобы успешно самореализовываться.

Осознают, что не владеют необходимыми знаниями и компетенциями для того, чтобы успешно самореализовываться в своей профессии, 43 \% студентов 3-го курса. 57 \% затрудняются ответить на данный вопрос. Среди студентов 4-го курса совершенно другая картина. Уверены, что обладают всем необходимым для того, чтобы профессионально самореализовываться, 36 \% четверокурсников, а 27 \% понимают, что, скорее всего, у них есть некий фундамент для дальнейшего развития. Затрудняются дать однозначный ответ на заданный вопрос 19 \% респондентов. Ощущают, что не обладают всем необходимым для своей дальнейшей профессиональной самореализации 18 \% студентов 4-го курса.

Следующий вопрос был направлен на то, чтобы выяснить, какие барьеры могут возникнуть у будущих учителей русского языка в ходе их профессиональной самореализации.

Студенты 3-го курса выделяют такие объективные трудности, как отсутствие практики (28 \% респондентов) и недостаточные методические знания ( $28 \%$ респондентов), а также неуверенность в себе (16\% респондентов). Все названные выше причины являются обоснованными. Респонденты данной группы еще только начали осваивать методические дисциплины «Теория и методика обучения русскому языку» и «Теория и методика обучения литературе», они ощущают свою неуверенность вследствие отсутствия педагогического опыта.

Опрос респондентов 4-го курса проводился сразу же после педагогической практики. Студенты уже побывали в роли учителя русского языка, поэтому они видят следующие барьеры в их профессиональной самореализации: неопределенность относительно будущей профессии (17\% респондентов), нехватка знаний в той или иной области 
Комарова Е. Н. Профессиональная самореализащия в представлении будущих учителей...

(17\% респондентов), отсутствие свободного времени у учителя русского языка (33\% респондентов).

Важно отметить, что респонденты обеих групп выделили для себя еще одну трудность, которая мешает им профессионально самореализовываться - отсутствие мотивации (28\% респондентов 3-го курса, 33 \% респондентов 4-го курса).

\section{Заключение}

Таким образом, на основе проведенного исследования можно сделать ряд выводов.

Самореализация представляет собой процесс развития личности, осуществление своих возможностей, предполагающее активную содеятельность с другими людьми, сотворчество, приложение собственных усилий. Необходимым условием этого процесса является самоактуализация - тенденция к самореализации, стремление реализовать свой потенциал, которое мобилизует внутреннюю силу личности. Самоактуализация существует во внутреннем плане личности (субъективный), а самореализация - во внешнем (объективный).

Мы выявили, что критической точкой в становлении будущего учителя русского языка является педагогическая практика. До практики в качестве основных трудностей самореализации студенты называют неуверенность в себе и нехватку знаний в области методических дисциплин. Эти трудности можно преодолеть в процессе учебной и учебнопрофессиональной деятельности. После педагогической практики основными барьерами самореализации становятся отсутствие свободного времени у учителя русского языка и высокая интенсивность работы, что заставляет студентов 4-го курса сомневаться в правильном выборе профиля профессиональной деятельности.

\section{Список литературы}

1. Маслоу А. Мотивация и личность. СПб.: Питер, 2009. 352 с.

2. Роджерс К. Взгляд на психотерапию. Становление человека. М.: Просвещение, 1994. 478 с.

3. Гольдштейн К. О двух формах приспособления к дефектам // Невропатология и психиатрия. 1940. Т. 9, вып. 6. С. 116-124.

4. Адлер А. Индивидуальная психология / авт.-сост. д-р филос. наук В. М. Лейбин. М.: Московский институт психоанализа, 2017. 488 с.

5. Колмогорова П. А. Самореализация личности современного человека: сб. науч. тр. по материалам Междунар. форума. Екатеринбург: Уральский гос. пед. ун-т, 2012. С. 202-205.

6. Абульханова-Славская К. А., Брушлинский А. В. Философско-психологическая концепция С. Л. Рубинштейна: К 100-летию со дня рождения. М.: Наука, 1989. 248 с.

7. Слободчиков В. И., Исаев Е. И. Основы психологической антропологии. Психология человека: Введение в психологию субъективности: учеб. пособие для вузов. М.: Школа-Пресс, 1995. 384 с.

8. Асмолов А. Г. Психология личности: культурно-историческое понимание развития человека. М.: Смысл: Издат. центр «Академия», 2007. $528 \mathrm{c}$.

9. Витин И. А. Теория самоактуализации // Психологический институт РАО: материалы симпозиума. М.: РАО, 2002. № 1. С. $139-143$.

10. Комарова Е. Н. Актуализация личностного потенциала и переживания жизненного благополучия человеком // European Social Science Journal. 2014. № 5-2 (44). C. 299-305.

11. Харламенкова Н. Е. Самоутверждение подростка. 2-е изд., испр. и доп. М.: Ин-т психологии РАН, 2007. 383 с.

12. Сабанчиева Р. 3. Акмеологические технологии успешной самореализации преподавателя высшей школы в профессиональной деятельности // Вестник КГУ. 2009. № 4. URL: https://cyberleninka.ru/article/n/akmeologicheskie-tehnologii-uspeshnoy-samorealizatsiiprepodavatelya-vysshey-shkoly-v-professionalnoy-deyatelnosti (дата обращения: 30.01.2019).

13. Маркова А. К. Психология профессионализма. М.: Международный гуманитарный фонд «Знание», 1996. 312 с.

14. Сластенин В. А. и др. Педагогика: учеб. пособие для студ. высш. пед. учеб. заведений. М.: Издат. центр «Академия», 2002. 576 с.

15. Сластенин В. А. Формирование личности учителя советской школы в процессе ее профессиональной подготовки: авторефр. дис. ... д-ра пед. наук. М., 1977. 29 с.

16. Шинкоренко А. В. Самоактуализация как фрактор профессионального развития педагога общеобразовательной школы // Проблемы и перспективы развития образования: материалы Междунар. науч. конф. Пермь: Меркурий, 2011. Т. I. С. 189-192. URL: https://moluch.ru/ conf/ped/archive/17/112/ (дата обращения: 30.01.2019).

17. Андриенко Е. В. Социальная психология: учеб. пособие для студ. высш. пед. учеб. заведений / под ред. В. А. Сластенина. М.: Академия, 2000. 264 C.

18. Sergeeva M. G., Donskaya M. V., Kolchina V. V., Machehina N. A., Zhirkova G. P., Shaleeva E. F. Model of psychological and pedagogical support of professional development of future specialists in the humanitarian profile // Espacios. 2018. № 39 (21). P. 23.

19. Gridchin A. M., Shutenko E. N., Shutenko A. I., Polyakov V. M., Ospishchev P. I. The use of modern information technology as the means students selfrealization in university Education // International Journal of Pharmacy and Technology. 2016. № 8 (4). P. 22687.

20. Shutenko E. N., Boyarinova I. V., Shapoval Z. A., Akimova A. R., Tsareva E. V. Psychological and didactic resources of use of information technologies as tools of students' self-fulfillment in university training // International Journal of Applied Engineering Research. 2017. № 12 (24). P. 15627-15634. 
Комарова Екатерина Николаевна, старший преподаватель, магистрант, Ивановский государственный университет (ул. Ермака, 37/7, Иваново, Россия, 153025). E-mail: kkatie1988@mail.ru

Материал поступил в редакизию 28.01.2019.

DOI: 10.23951/1609-624X-2020-1-61-69

\title{
PROFESSIONAL SELF-REALIZATION IN THE IDEA OF FUTURE TEACHERS OF THE RUSSIAN LANGUAGE
}

\section{E. N. Komarova}

\author{
Ivanovo State University, Ivanovo, Russian Federation
}

Introduction. The most important task of modern education is to provide opportunities for personal and professional growth and for the implementation of self-realization. The main approaches to the study of the concept of selfrealization are outlined. The results of a survey of future teachers of the Russian language are presented. The ideas of future teachers of the Russian language in relation to their professional self-realization are revealed.

Material and methods. The study was conducted on the basis of the analysis of theoretical sources on the problem of self-realization and the results of a survey of students of the philological faculty. The author's questionnaire consisted of 3 open-ended questions and 4 closed-ended questions.

Results and discussion. Various approaches to understanding these concepts are analyzed and their own position on this issue is substantiated. According to the results of the survey, it was found that $15 \%$ of 3-year students and $55 \%$ of 4-year students are sure that professional self-realization implies continuous improvement in the chosen profession and the need for improvement. The needs arising for future teachers of the Russian language during pedagogical practice, which is a key link between the theoretical training of future teachers of the Russian language and their independent work in an educational institution, are characterized.

Conclusion. Self-actualization is understood as a tendency to self-realization. And self-realization is a process of personality development, involving active cooperation with other people, the application of one's own efforts. It is revealed that the pedagogical practice is a critical point in the formation of the future teacher of the Russian language. Before practice, the main difficulties for students are self-doubt and lack of knowledge in the field of methodological disciplines. After teaching practice, the lack of free time among teachers of the Russian language and the high intensity of work become the basic barriers for self-realization for students. This makes future teachers of the Russian language doubt their further professional activities. The question arises of the psychological and pedagogical support of students during practice.

Keywords: self-realization, self-actualization, professional self-realization, future teachers of the Russian language, barriers to professional self-realization.

\section{References}

1. Maslou A. Motivatsiya i lichnost' [Motivation and personality]. Saint Petersburg, Piter Publ., 2009. 352 p. (in Russian).

2. Rodzhers K. Vzglyad na psikhoterapiyu. Stanovleniye cheloveka. Moscow, Prosveshcheniye Publ., 1994. 478 p. (in Russian).

3. Gol'dshteyn K. O dvukh formakh prisposobleniya k defektam [About two forms of adaptation to defects]. Nevropatologiya i psikhiatriya, 1940 , vol. 9, no. 6. p. 116-124 (in Russian).

4. Adler A. Individual'naya psikhologiya. Avt.-sost. dokt. filos. nauk V. M. Leybin [Individual psychology. Author-composer Doctor of Philosophy V. M. Leibin]. Moscow, Moscow Institute of Psychoanalysis Publ., 2017. 488 p. (in Russian).

5. Kolmogorova P. A. Samorealizatsiya lichnosti sovremennogo cheloveka. Sbornik nauchnykh trudov po materialam Mezhdunarodnogo foruma [Self-realization of the personality of a modern person]. Ekaterinburg, Ural State Pedagogical University Publ., 2012. Pp. $202-205$ (in Russian).

6. Abul'khanova-Slavskaya K. A., Brushlinskiy A. V. Filosofsko-psikhologicheskaya kontseptsiya S. L. Rubinshteyna: K 100-letiyu so dnya rozhdeniya [Philosophical and psychological concept of S. L. Rubinstein: On the occasion of the 100th anniversary of his birth]. Moscow, Nauka Publ., 1989. 248 p. (in Russian).

7. Slobodchikov V. I., Isayev E. I. Osnovy psikhologicheskoy antropologii. Psikhologiya cheloveka: Vvedeniye v psikhologiyu sub"yektivnosti: ucheb. posobiye dlya vuzov [Fundamentals of Psychological Anthropology. Human Psychology: An Introduction to the Psychology of Subjectivity: A Textbook for High Schools]. Moscow, Shkola-Press Publ., 1995. 384 p. (in Russian).

8. Asmolov A. G. Psikhologiya lichnosti: kul'turno-istoricheskoye ponimaniye razvitiya cheloveka [Psychology of personality: cultural and historical understanding of human development]. Moscow, Smysl, Izdatel'sky tsentr «Akademiya» Publ., 2007. 528 p. (in Russian).

9. Vitin I. A. Teoriya samoaktualizatsii [Self-actualization theory]. Psikhologicheskiy institut RAO: materialy simpoziuma [Psychological Institute of RAO: proceedings of the symposium]. Moscow, RAE Publ., 2002, no. 1, p. 139-143 (in Russian).

10. Komarova E. N. Aktualizatsiya lichnostnogo potentsiala i perezhivaniya zhiznennogo blagopoluchiya chelovekom [Actualization of personal potential and experience of human well-being]. European Social Science Journal, 2014, no. 5-2 (44), pp. 299-305 (in Russian). 
Комарова Е. Н. Профессиональная самореализащия в представлении будущих учителей...

11. Kharlamenkova N. E. Samoutverzhdeniye podrostka [Self-affirmation of a teenager]. 2-e izd., ispr. i dop. Moscow, Psychology Institute RAS Publ., 2007. 383 p.(in Russian).

12. Sabanchiyeva R. Z. Akmeologicheskiye tekhnologii uspeshnoy samorealizatsii prepodavatelya vysshey shkoly v professional'noy deyatel'nosti [Acmeological technologies of successful self-realization of a higher school teacher in professional activities]. Vestnik KGU - Vestnik of Kostroma State University, 2009, no. 4 (in Russian). URL: https://cyberleninka.ru/article/n/akmeologicheskie-tehnologii-uspeshnoy-samorealizatsiiprepodavatelya-vysshey-shkoly-v-professionalnoy-deyatelnosti (accessed 30 January 2019).

13. Markova A. K. Psikhologiya professionalizma [The psychology of professionalism]. Moscow, Mezhdunarodnyy gumanitarnyy fond «Znaniye» Publ., 1996. 312 p. (in Russian).

14. Slastenin V. A. et al. Pedagogika: ucheb. posobiye dlya stud. vyssh. ped. ucheb. zavedeniy [Pedagogy: a textbook for students of higher pedagogical educational institutions]. Moscow, Akademiya Publ., 2002. 576 p. (in Russian).

15. Slastenin V. A. Formirovaniye lichnosti uchitelya sovetskoy shkoly v protsesse eye professional'noy podgotovki. Avtoref. dis. ... dokt. ped. nauk [The formation of the personality of the teacher of the Soviet school in the process of its training. Abstract of thesis doct. of ped.sci.]. Moscow, 1977. 29 p. (in Russian).

16. SHinkorenko A. V. Samoaktualizatsiya kak faktor professional'nogo razvitiya pedagoga obshcheobrazovatel'noy shkoly [Self-actualization as a factor in the professional development of a secondary school teacher]. Problemy i perspektivy razvitiya obrazovaniya: materialy Mezhdunar. nauch. konf. T. I [Problems and Prospects for the Development of Education: materials of the International Scientific Conference. Vol. I]. Perm, Merkuriy Publ., 2011. p. 189-192 (in Russian). URL https://moluch.ru/conf/ped/archive/17/112/ (accessed 30 January 2019).

17. Andriyenko E. V. Sotsial'naya psikhologiya: ucheb. posobiye dlya stud. vyssh. ped. ucheb. zavedeniy. Pod red. V. A. Slastenina [Social Psychology: textbook for students of higher educational institutions. Edited by V. A. Slastenin]. Moscow, Akademiya Publ., 2000. 264 p. (in Russian).

18. Sergeyeva M. G., Donskaya M. V., Kolchina V. V., Machehina N. A., Zhirkova G. P., Shaleyeva E. F. Model of psychological and pedagogical support of professional development of future specialists in the humanitarian profile. Espacios, 2018, no. 39 (21), p. 23.

19. Gridchin A. M., Shutenko E. N., Shutenko A. I., Polyakov V. M., Ospishchev P. I. The use of modern information technology as the means students selfrealization in university Education. International Journal of Pharmacy and Technology, 2016, no. 8 (4), p. 22687.

20. Shutenko E. N., Boyarinova I. V., Shapoval Z. A., Akimova A. R., Tsareva E. V. Psychological and didactic resources of use of information technologies as tools of students' self-fulfillment in university training. International Journal of Applied Engineering Research, 2017, no. 12 (24), pp. 15627-15634.

Komarova E. N., Ivanovo State University (ul. Yermaka, 37/7, Ivanovo, Russian Federation, 153025).

E-mail: kkatie1988@mail.ru 